\title{
Methanogenesis in an Impacted and Two Dystrophic Coastal Lagoons (Macaé, Brazil)
}

\author{
André Luiz dos Santos Furtado ${ }^{1 *}$; Peter Casper ${ }^{2}$ and Francisco de Assis Esteves ${ }^{3}$ \\ ${ }^{1}$ Agência Nacional de Águas, Superintendência de Informações Hidrológicas, Setor Policial Sul, Área 5, Quadra \\ 3, Brasília, DF, Brazil, CEP: 70.610-200. e.mail: furtado@ana.gov.br. ${ }^{2}$ Leibniz-Institute of Freshwater Ecology \\ and Inland Fisheries, Department of Stratified Lakes, Alte Fischerhütte 2, D16775, Stechlin-Neuglobsow, \\ Germany.e.mail: pc@igb-berlin.de. ${ }^{3}$ Universidade Federal do Rio de Janeiro, Inst. de Biologia, Departamento de \\ Ecologia, Cidade Universitária, Ilha do Fundão, Rio de Janeiro, Brazil, CEP: 21.941-590. \\ e.mail:festeves@biologia.ufrj.br
}

\begin{abstract}
This study investigated the methanogenic activity in sediment of the Imboacica (human impacted), Cabiunas and Comprida coastal lagoons in Rio de Janeiro State (Brazil). Methane was not detected in water and sediment samples from the three lagoons. The measured nutrient concentrations in the pore-water indicated that methanogens activity was not limited by nutrients. Methanogenic activity was not detected under in vitro conditions, indicating that terminal organic carbon mineralisation via methanogenesis was negligible for the top $6 \mathrm{~cm}$ of sediment at the sampling time.
\end{abstract}

Key words: Coastal lagoon, methane, sediment, nutrients

\section{INTRODUCTION}

The increased human population in the coastal area of Rio de Janeiro State led to eutrophication of the lagoons in this region. Generally, the anthropogenic influence is mainly limited to that lagoons situated close to urban areas. Located in Macaé City the Imboacica lagoon has been exposed to increasing population density, receiving daily discharge of 70 $\mathrm{kg} \mathrm{N}$ and $7 \mathrm{~kg} \mathrm{P}$ due to loading of sewage (LopezFerreira 1995). The temporarily opening of the sandbar causes the drainage of the lagoon to the ocean, influencing strongly the lagoon metabolism (Faria et al. 1998). In contrast, located in the National Park Restinga de Jurubatiba, the dystrophic Cabiúnas and Comprida lagoons can be considered as undisturbed ecosystems. Previous field studies have shown that the extension of marine influence vary among the lagoons, with higher values of $\mathrm{pH}$, conductivity, and salinity in the Imboacica lagoon than in the Cabiúnas and Comprida lagoons (Petrucio 1998).

Several ecological aspects of these lagoons were investigated intensively since 1992 (Esteves 1998).

\footnotetext{
* Author for correspondence
} 
However, studies on benthic microbial activity in these lagoons focused only on nitrogen fixation (Furtado and Esteves 1997, Biesboer et al. 1998).

The purpose of this study was to investigate the methanogenic activity and the methane distribution pattern in the sediments and in the water bodies of the Imboacica, Cabiúnas and Comprida lagoons. Methanogenesis depends strongly on sediment composition, especially the contents of organic carbon, nitrogen, phosphorus, etc. The particulate and the dissolved components of the sediments of the investigated lagoons have also been described also in this study.

\section{MATERIAL AND METHODS}

The study was conducted in the Imboacica, Cabiúnas and Comprida lagoons situated in the coastal area of the State of Rio de Janeiro (Brazil) $\left(22^{\circ} 50^{\prime} \mathrm{S}-44^{\circ} 42^{\prime} \mathrm{W}\right)$. The regional climate is warm and humid; the annual average minimum and maximum temperatures are 18.7 and $27.4{ }^{\circ} \mathrm{C}$ with lowest precipitation in winter $(43.8 \mathrm{~mm})$ and highest in summer $(185.8 \mathrm{~mm})$ (FIDERJ 1977). The lagoons are separated by a sandbar (approximately $100 \mathrm{~m}$ ) from the Atlantic Ocean. Morphological and limnological characteristics of the lagoons were described in detail by Panosso et al. (1998) and Petruccio (1998). In contrast to the impacted Imboacica lagoon, the Cabiúnas and Comprida lagoons can be considered as undisturbed with black-coloured water due to humic compounds from the so-called "Restinga" (sand-dune habitats in coastal area of Brazil).

Samples were taken from all sites in August 1995. The site 1 was located near the sandbar (seaward position) and the site 2 in the opposite direction (landward position), which is colonised by macrophytes and receive an input of freshwater by loading of small streams. In Imboacica lagoon, site 1 and 2 were close to the town and impacted by anthropogenic effects. The sediment of the lagoons is characterised mainly by the presence of small and large sandy particles, which stood for more than $30 \%$ of the sediment granulometry (Gonçalves et al. 1998).

Water samples were taken using a van Dorn sampler from water surface and near the bottom (above sediment). Water temperature was measured using a Cole Parmer thermistor Model 8402-10. Samples for oxygen analyses were fixed in the field and determined by Winkler method. Salinity and conductivity were measured with a LabComp SCT, pH with a pH Micronal B278. Alkalinity was determined according to Carmouze (1994).

Total phosphorus (TP), dissolved phosphorus (DP) and soluble reactive phosphorus (SRP) were determined according to Golterman et al. (1978). Analyses of nitrate were based on Mackereth et al. (1978) and of ammonium on Koroleff (1983). Organic (OC) and inorganic carbon (IC) was measured using a TOC 5000 Analyser (Shimadzu). Dissolved nutrients were determined after filtration (GF 52/C, (Schleicher and Schüll, Germany).

Undisturbed sediment samples were collected using a gravity core sampler as described in Ambühl and Bührer (1975). Directly after coring sediments were divided in 2 fractions: $0-3 \mathrm{~cm}$ and 3-6 cm. Pore water was extracted by filtering the sediment (Sartorius SM 143 filter) under nitrogen pressure. Concentration of total phosphorus, ammonium, nitrate and dissolved organic carbon in pore water were measured as described for water samples. Sediment organic matter was determined by combusting samples at $550^{\circ} \mathrm{C}$ for 4 hours and organic carbon was obtained by oxidation with potassium dichromate (Hungria and Araujo 1994). Total phosphorus (TP) was determined as described in Fassbender (1974). After extraction with $2 \mathrm{M} \mathrm{KCl}$ (Alves et al. 1993) ammonium and nitrate were measured as described.

Methane concentration and production were processed according to Casper (1992). In the field $2 \mathrm{ml}$ water were given (bubble free) into a $7 \mathrm{ml}$ flask, $2 \mathrm{ml} \mathrm{NaOH} \mathrm{(4 \% )} \mathrm{were} \mathrm{added} \mathrm{and} \mathrm{the} \mathrm{flasks}$ quickly closed with rubber septa and intensively shacked to degas the methane. Methane concentration in the headspace was determined using a gas chromatograph (Shimadzu GC 14A) equipped with FID detection and a $1 \mathrm{~m}$ Porapack Q stell-column. $\mathrm{N}_{2}$ was used as carrier gas.

For the estimation of methane production sediment samples $(2 \mathrm{ml})$ were added to a flask $(7 \mathrm{ml})$ with 2 $\mathrm{ml}$ of sterile lagoon water. Controls were done by $\mathrm{CHCl}_{3}$ addition. Before incubation a flux of nitrogen was done. Samples were incubated in the 
laboratory at in situ temperature in the dark and subsamples of the headspace were removed and analysed after one and two weeks.

\section{RESULTS}

Limnological parameters: Basic limnological parameters measured at the sampling day are given in Table 1. Lagoon Comprida was characterised by lowest values of conductivity $(0.4$ $\left.\mathrm{mS} \mathrm{cm}{ }^{-1}\right)$ and alkalinity $\left(0 \mathrm{mEq} \mathrm{I}^{1}\right)$. The salinity at the sampling stations of the Cabiúnas and Comprida lagoons was zero, contrasting with the high values at the stations of the Imboacica lagoon (15). Water temperature did vary from 21.3 in the Imboacica lagoon to $25.7{ }^{\circ} \mathrm{C}$ in the Cabiúnas lagoon. In the shallow lagoons oxygen concentrations were high $\left(6.5-8.7 \mathrm{mg} \mathrm{I}^{1}\right)$ except above sediment in the Cabiúnas lagoon land site 2 $\left(0.2 \mathrm{mg}^{-1}\right)$.

Water samples: The highest values of all nutrients were measured in the Imboacica lagoon, except organic carbon (Table 2). The concentration of total phosphorus was closed to $0.04 \mu \mathrm{mol}^{-1}$ in both undisturbed lagoons and reached $026 \mu$ mol $\mathrm{I}^{1}$ in the Imboacica lagoon. The concentrations of dissolved phosphorus and SRP (soluble reactive phosphorus) showed the same trend with high values in the Imboacica lagoon and low values in the Cabiúnas and Comprida lagoons. Although the observed nitrate concentrations of the Cabiúnas, Imboacica and Comprida lagoons were somehow

Table 1 - Measurements of depth, temperature (temp.), Secchi Disk (S.D.), conductivity (cond.), salinity (sal.), pH, alkalinity (alk.) and oxygen (oxyg.) in the Lagoons Imboacica, Cabiúnas and Comprida

\begin{tabular}{|c|c|c|c|c|c|c|c|c|c|c|}
\hline Lagoon & Site & & $\begin{array}{c}\text { Depth } \\
\text { m }\end{array}$ & $\begin{array}{l}\text { Temp. } \\
{ }^{\circ} \mathrm{C}\end{array}$ & $\begin{array}{c}\text { S. D. } \\
\text { m }\end{array}$ & $\begin{array}{l}\text { Cond. } \\
\mathrm{mS} \mathrm{cm}^{-1}\end{array}$ & Sal. & $\mathrm{pH}$ & $\begin{array}{c}\text { Alk. } \\
\mathrm{mEq} 1^{-1}\end{array}$ & $\begin{array}{l}\text { Oxyg } \\
\mathrm{mg}^{-1}\end{array}$ \\
\hline \multirow[t]{2}{*}{ Imboacica } & 1 & surface & 0.1 & 22.4 & $>1.2$ & 10.9 & 15 & 7.90 & 320.8 & 8.7 \\
\hline & & bottom & 1.2 & 21.3 & & 12.4 & 15 & 7.61 & 317.8 & 8.3 \\
\hline Imboacica & 2 & _- & 0.3 & 24.9 & $>0.45$ & 11.2 & 15 & 4.45 & 514.3 & 7.4 \\
\hline \multirow[t]{2}{*}{ Cabiúnas } & 1 & surface & 0.1 & 24.6 & 1.1 & 0.48 & 0 & 6.53 & 236.6 & 7.1 \\
\hline & & bottom & 3.0 & 24.6 & & 0.53 & 0 & 6.70 & 261.4 & 6.8 \\
\hline \multirow[t]{2}{*}{ Cabiúnas } & 2 & surface & 0.1 & 25.7 & 1.15 & 0.56 & 0 & 6.46 & 333.3 & 7.1 \\
\hline & & bottom & 2.1 & 22.0 & & 0.59 & 0 & 5.93 & 320.0 & 0.2 \\
\hline \multirow[t]{2}{*}{ Comprida } & 1 & surface & 0.1 & 23.6 & 0.35 & 0.40 & 0 & 4.80 & 0 & 7.8 \\
\hline & & bottom & 2.3 & 23.3 & & 0.43 & 0 & 5.13 & 24.5 & 7.6 \\
\hline \multirow[t]{2}{*}{ Comprida } & 2 & surface & 0.1 & 24.4 & 0.55 & 0.45 & 0 & 5.30 & 35.0 & 6.5 \\
\hline & & bottom & 0.9 & 23.4 & & 0.51 & 0 & 5.60 & 36.1 & 6.6 \\
\hline
\end{tabular}

similar, presenting an increasing tendency $(1.05-$ $1.19 \mu \mathrm{mol} \mathrm{I} \mathrm{I}^{1}, 1.32-2.05 \mu \mathrm{mol} \mathrm{I}^{1}$, and $1.38-2.44$ $\mu \mathrm{mol} \mathrm{I}^{-1}$ respectively). High concentration of ammonium was measured at site 2 of the Imboacica lagoon $\left(20.37 \mu \mathrm{mol} \mathrm{I} \mathrm{I}^{1}\right)$, with the others stations showing reduced values of ammonium, which were lower than $7.0 \mu \mathrm{mol} \mathrm{I}^{-1}$.

The concentration of total organic carbon (TOC) was high at all stations of the Comprida lagoon and at the station 2 of the Imboacica lagoon (> $20.0 \mathrm{mg}$ $\mathrm{I}^{-1}$ ). The concentration of inorganic carbon varied from $0.2 \mathrm{mg} \mathrm{I}^{1}$ at site 1 of the Comprida lagoon to $1.2 \mathrm{mg}^{-1}$ at site 1 of the Cabiúnas lagoon. Generally, there was no difference in the concentrations of nutrients measured at stations located near the sea site and the stations near landsite, colonised by macrophytes. At the same time, similar concentration of nutrients were measured at the surface and at the bottom of the lagoons, excepting for the concentration of SRP, ammonium and organic carbon at stations of the Imboacica lagoon.

Pore Water Nutrients: The impacted Imboacica lagoon showed highest concentration of dissolved organic carbon (465.7 $\left.\mu \mathrm{g} \mathrm{I}^{-1}\right)$ and ammonium 32.62 $\mu$ mol $\mathrm{l}^{1}$ (Table 3 ) in pore water. But, the others lagoons considered as undisturbed generally 
showed high concentration of dissolved nutrients in pore water samples. For example, the concentration of SRP at the sediment layer 0-3 cm of the Comprida lagoon $\left(3.63 \mu \mathrm{mol} 1^{1}\right)$ was 40 times higher than the concentration measured at the same sediment depth of the Imboacica lagoon $\left(0.09 \mu \mathrm{mol} \mathrm{I}^{-1}\right)$.

The lowest $\left(4.57 \mu \mathrm{mol} \mathrm{I}^{1}\right)$ and the highest (8.21 $\mu \mathrm{mol} \mathrm{I}^{1}$ ) concentrations of nitrate were detected in the Comprida lagoon. The concentration of dissolved organic carbon was similar in all lagoons, excepting at 3-6 cm sediment layer of site 2 of the Imboacica lagoon. The highest concentrations of dissolved inorganic carbon were obtained in the Cabiúnas lagoon and the lowest in the Imboacica lagoon.

No clear trend was observed comparing the samples from surface and the deeper layer of sediment samples. However, the concentration of dissolved nutrients at the upper samples from the Comprida lagoon was higher than in bottom samples (Table 3).

Nutrients in sediment samples: In some stations, the content of nutrients was lower than the detection limit as for total phosphorus and organic carbon at the sediment layer 3-6 $\mathrm{cm}$ at site 2 of the Cabiúnas lagoon (Table 4). As observed for other measurements verified in this study, there was not a clear trend and recent sediment layers (upper layer) did not show higher content of nutrients that older layers (bottom layer). Sampling sites 1 of the Imboacica lagoon and 2 of the Cabiúnas lagoon were characterised by very sandy sediments with low content of organic matter (less than $1 \%$ of dw). Site 1 of the Comprida lagoon was the site with organic richest sediment $(82.7 \%$ OM; $38.1 \%$ OC). The total phosphorus content varied from $0.0013 \% \mathrm{dw}$ in the 3-6 sediment layer at site 2 of the Comprida lagoon to $0.0529 \%$ dw in the

Table 2 - Concentration of total phosphorus (TP), dissolved phosphorus (DP), soluble reactive phosphorus (SRP), nitrate, ammonium $\left(\mathrm{NH}_{4}\right)$, total organic carbon (TOC) and total inorganic carbon (TIC) in water samples of the Imboacica, Cabiúnas and Comprida lagoons

\begin{tabular}{|c|c|c|c|c|c|c|c|c|c|}
\hline & Site & & $\mathrm{TP}$ & DP & $\begin{array}{c}\text { SRP } \\
\mu_{\mathrm{mol} \mathrm{l}}^{-1}\end{array}$ & Nitrate & $\mathrm{NH}_{4}$ & TOC & TIC \\
\hline \multirow[t]{2}{*}{ Imboacica } & 1 & surface & 0.16 & 0.28 & 0.24 & 1.32 & 6.75 & 15.3 & 0.5 \\
\hline & & bottom & 0.17 & 0.08 & 0.05 & 2.05 & 6.79 & 14.2 & 0.5 \\
\hline Imboacica & 2 & - & 0.26 & 0.03 & 0.001 & 1.58 & 20.37 & 27.2 & 0.3 \\
\hline \multirow[t]{2}{*}{ Cabiúnas } & 1 & surface & 0.04 & 0.03 & 0.004 & 1.19 & 3.91 & 14.1 & 1.2 \\
\hline & & bottom & 0.03 & 0.03 & 0.02 & 1.05 & 3.82 & 14.9 & 0.5 \\
\hline \multirow[t]{2}{*}{ Cabiúnas } & 2 & surface & 0.04 & 0.09 & 0.06 & 1.18 & 3.72 & 10.1 & 3.5 \\
\hline & & bottom & 0.03 & 0.01 & 0 & 1.05 & 3.72 & 13.2 & 2.0 \\
\hline \multirow[t]{2}{*}{ Comprida } & 1 & surface & 0.05 & 0.03 & 0.03 & 2.44 & 4.94 & 23.2 & 0.2 \\
\hline & & bottom & 0.05 & 0.05 & 0.04 & 1.38 & 4.94 & 20.3 & 0.2 \\
\hline \multirow[t]{2}{*}{ Comprida } & 2 & surface & 0.05 & 0.03 & 0.02 & 1.91 & 4.94 & 24.1 & 0.7 \\
\hline & & bottom & 0.05 & 0.03 & 0.03 & 1.78 & 5.23 & 23.9 & 0.7 \\
\hline
\end{tabular}

sediment layer 3-6 at site 1 of the Cabiúnas lagoon. As described for phosphorus, the lowest contents of nitrate and ammonium (0.0016 and $0.0029 \% \mathrm{dw}$, respectively) were obtained in the Cabiúnas lagoon.

Methane Concentration and Methane Production: Methane concentration was below the detection limit of $0.1 \mu \mathrm{mol} \mathrm{I}^{1}$ in all investigated water samples as well as in all pore water samples. After incubation for two weeks no methane production was found in any sediment of the lagoons.

\section{DISCUSSION}

The sampling was done after the artificial opening 
of the sandbar of the Imboacica lagoon that occurred in $29^{\text {th }}$ March 1995. This explained the low depth at site 2 and the higher values of salinity, conductivity and alkalinity. Usually, the Imboacica lagoon showed higher values of nutrients in the water column than the dystrophic Lagoons Cabiúnas and Comprida. This pattern was not clearly observed for the concentrations of nutrients in the pore water and in the sediment. For example, Comprida lagoon showed higher concentration of SRP and nitrate in pore water samples and ammonium, organic matter and organic carbon in sediment samples than in samples from the Imboacica lagoon.

Deposited organic matter underlies various mineralisation processes in sediments like aerobic respiration, denitrification, desulphurication and others. In many freshwater sediment systems, methanogenesis is the dominating terminal mineralisation process under anaerobic conditions. Methane production depends as a microbial process on the availability of electron donors (organic substances) (Whiticar 1996) under low redox potential $(<-200 \mathrm{mV}$ ) (Ratering and Conrad 1998), on temperature (Segers 1998), on inhibitory effects by diverse substances (Akesson and Nilsson 1998) or organisms and other parameters. At all studied sites neither methane production nor traces of methane in sediment pore water or overlying water could be detected. Even in the lagoons with typical freshwater conditions as Cabiúnas and Comprida lagoons, which were characterized by high organic matter content in the sediments (Table 4). Zaiss (1996) found a high methanogenic activity for water bodies as streams, rivers and lakes that presented high organic matter, excepting salt marsh sediments. Only in the Imboacica lagoon high values of conductivity and salinity (Table 1) were observed. These more marine conditions could be the reason for missing methanogenic activity.

The concentration of methane depends on the balance between methane production in the deeper anaerobic zone of freshwater sediments and it's consumption at the anoxic-oxic boundary layer. A total loss of produced methane due to oxidation within the sediments would coincide with an oxygen penetration depth of more than $6 \mathrm{~cm}$ in all sites. That is unlikely for freshwater sediments where only a penetration of millimeters were

Table 3 - Concentration of soluble reactive phosphorus (SRP), nitrate, ammonium, total organic carbon (TOC) and total inorganic carbon (TIC) in the pore water samples of the Imboacica, Cabiúnas and Comprida lagoons

\begin{tabular}{lccccccc}
\hline Lagoon & Site & $\begin{array}{c}\text { Depth } \\
\mathrm{cm}\end{array}$ & SRP & $\begin{array}{c}\text { Nitrate } \\
\mu \mathrm{mol} 1^{-1}\end{array}$ & Ammonium & TOC & TIC \\
\hline Imboacica & 1 & $0-3$ & 0.07 & 5.69 & 22.76 & 19.0 & 2 \\
Imboacica & 2 & $0-3$ & 0.09 & 5.56 & 32.62 & 27.0 & 0.6 \\
& & $3-6$ & 0.14 & 4.57 & 24.52 & 465.7 & 1.9 \\
Cabiúnas & 1 & $0-3$ & 0.26 & 7.42 & 13.73 & 23.8 & 8.2 \\
& & $3-6$ & 0.11 & 4.63 & 6.84 & 13.9 & 3.1 \\
Cabiúnas & 2 & $0-3$ & 0.27 & 7.35 & 15.44 & 24.4 & 9.6 \\
& & $3-6$ & 0.35 & 7.02 & 27.98 & 28.4 & 15.0 \\
Comprida & 1 & $0-3$ & 0.23 & 7.09 & 10.26 & 23.8 & 4.6 \\
& & $3-6$ & 0.17 & 4.57 & 10.36 & 19.3 & 3.0 \\
Comprida & 2 & $0-3$ & 3.63 & 8.21 & 15.19 & 31.1 & 4.6 \\
& & $3-6$ & 0.49 & 7.88 & 14.80 & 29.6 & 4.7 \\
\hline
\end{tabular}

Table 4 - Content of total phosphorus (TP), nitrate, ammonium, organic matter (OM), and organic carbon (OC) in sediment samples of the Imboacica, Cabiúnas and Comprida lagoons

\begin{tabular}{lccccccc}
\hline Lagoon & Site & $\begin{array}{c}\text { Depth } \\
\mathrm{cm}\end{array}$ & TP & Nitrate & $\begin{array}{c}\text { Amonium } \\
\text { \% dry weigth }\end{array}$ & OM & OC \\
\hline Imboacica & 1 & $0-3$ & 0.0032 & 0.0035 & 0.0029 & 0.66 & 0.19 \\
& & $3-6$ & 0.0030 & 0.0041 & 0.0030 & 0.79 & 0.0007 \\
Imboacica & 2 & $0-3$ & 0.0342 & 0.0086 & 0.0058 & 15.89 & 3.90
\end{tabular}




\begin{tabular}{|c|c|c|c|c|c|c|c|}
\hline & & $3-6$ & 0.0231 & 0.0076 & 0.0058 & 11.24 & 0.60 \\
\hline \multirow[t]{2}{*}{ Cabiúnas } & 1 & $0-3$ & 0.0446 & 0.0020 & 0.0040 & 11.74 & 1.19 \\
\hline & & $3-6$ & 0.0529 & 0.0028 & 0.0036 & 19.10 & 1.36 \\
\hline \multirow[t]{2}{*}{ Cabiúnas } & 2 & $0-3$ & 0.0021 & 0.0022 & 0.0029 & 0.28 & $*$ \\
\hline & & $3-6$ & $*$ & 0.0016 & $*$ & 0.18 & $*$ \\
\hline \multirow[t]{2}{*}{ Comprida } & 1 & $0-3$ & 0.0257 & 0.0026 & 0.0039 & 63.85 & 33.61 \\
\hline & & $3-6$ & 0.0080 & 0.0059 & 0.0403 & 82.68 & 38.10 \\
\hline \multirow[t]{2}{*}{ Comprida } & 2 & $0-3$ & 0.0056 & 0.0031 & 0.0140 & 6.72 & 4.36 \\
\hline & & $3-6$ & 0.0013 & 0.0028 & 0.0056 & 11.27 & 2.56 \\
\hline
\end{tabular}

described (Sass et al. 1997, Luther et al. 1998). Methanogens are unable to assimilate polymeric organic compounds directly. Their activity depends on substrate availability as acetate or hydrogen resulting from fermentative activity of other microbes at the site. These substrates are also utilised by others microorganisms as sulphate reducing bacteria (SRB), which show higher affinity for substrate and higher substrate removal rate than methanogens (Harada et al. 1994). Unfortunately studies on sulphur metabolism were never performed in these lagoons. A substrate limitation could be a possible explanation for the failing methanogenic activity in the top $6 \mathrm{~cm}$ of sediment.

Another reason could be found in the abundance of methanogens at site. Methanogens belonging to the kingdom of Archaeas have been observed in marine and freshwater anoxic environments, colonising even habitats, which show adverse conditions (Boon et al. 1997, Takai and Salo 1999). This study was done under in vitro conditions, which were favourable for growth of methanogens (anoxic conditions, darkness and constant temperature, 2 weeks incubation). It seems that the abundance of methanogens was very low in the sediments of the coastal lagoons in Macaé. This result agrees whit further observation that did not find significant amount of methanogenic biomarkers in the sediment of the lagoons (data not shown). However, recently benthic activity of methanogens has been detected in situ studies along the year in the superficial sediment layers (from 0 to $10 \mathrm{~cm}$ ) of the Imboacica, Cabiúnas and Comprida lagoons. Then, it is possible that the microbial structure of these lagoons could be atypical, when compared with other water bodies. There was not observed any relationship between trophic status and methanogenic activity. Methane was not produced in the oligotrophic lagoons or in the impacted lagoon. Methanogenesis did not participate on organic matter mineralisation in the top $6 \mathrm{~cm}$ of sediments in the Imboacica, Cabiúnas and Comprida lagoons at the sample date. Although these lagoons are not a major contributor of methane to the troposphere they can be used as a natural laboratory to compare the effect of anthropogenic and marine influence on freshwater ecosystems and on methane metabolism in particular.

The Imboacica lagoon received an input of sewage, explaining the high concentration of nutrients in the water column. In contrast, the concentration of nutrients in the sediment of this lagoon was lower than in the studied dystrophic lagoons. The artificial opening of the sandbar of the Imboacica lagoon caused a water flow from the lagoon to the sea, leading to an outwash of superficial sediment layers, which probably reduced the concentration of nutrients in the sediment, dropping the internal fertilization from the sediment to the water column.

\section{ACKNOWLEDGEMENTS}

We thank Dr. Marcos Callisto for the assistance with sampling in the field and for fruitful discussions.

\section{RESUMO}

O objetivo deste estudo foi investigar a atividade metanogênica no sedimento das lagoas Imboacica, Cabiúnas e Comprida (Macaé, Rio de Janeiro). As amostras de água e sedimento foram coletadas em duas estações em cada lagoa. A atividade 
metanogênica nas três lagoas foi abaixo do limite de detecção do método utilizado (cromatografia gasosa). Os resultados obtidos indicaram que a atividade metanogênica não foi limitada pela concentração de nutrientes na água intersticial. Sob condições experimentais, a atividade metanogênica foi nula, indicando que a mineralização do carbono orgânico via metanogênese foi desprezível nas três lagoas durante o período amostrado.

\section{REFERENCES}

Akesson, M. and Nilsson, P. (1998), Material dependence of methane production rates in landfills. Waste Management and Research, 16, 108-118.

Alves, B. J .R.; Boddey, R. M. and Urquiaga, S. S. (1993), A rapid sensitive flow injection technique for the analysis of ammonium in soil extracts. Communications in Soil Science and Plant Analysis, 24, 277-284.

Ambühl, H. and Bührer, H. (1975), Zur Technik der Entnahme ungestörter Großproben von Seesedimenten: ein verbessertes Bohrlot. Schweizerische Zeitschrift für Hydrologie, 37, 175186.

Biesboer, D. D.; Esteves, F. A. and Enrich-Prast, A. (1998), Nitrogen fixation and denitrification in Lagoa Imboacica, a coastal lagoon of Rio de Janeiro State, Brazil. Verhandlungen der Internationalen Vereinigung für Theoretische und Angewandte Limnologie, 26, 1412-1417.

Boon, P. I.; Mitchell, A. and Lee, K. (1997), Effects of wetting and drying on methane emissions from ephemeral floodplain wetlands in south-eastern Australia. Hydrobiologia, 357, 73-87.

Carmouze, J. P. (1994), O metabolismo dos ecossistemas aquáticos. Fundamentos teóricos, métodos de estudo e análises químicas. Ed. Edgard Blucker/FAPESP, São Paulo.

Casper, P. (1992), Methane production in lakes of different trophic state. Archiv für Hydrobiologie Beihefte Ergebnisse der Limnologie, 37, 149-154.

Esteves, F. A. (1998), Ecologia das lagoas costeiras do Parque Nacional da Restinga de Jurubatiba e do Município de Macaé, (RJ). UFRJ/NUPEM, Rio de Janeiro.

Faria, B. M.; Suzuki, M. S.; Petrucio, M. M. and Prast, A. E. (1998), Changes in the metabolism of a Brazilian lagoon related to man-made marine entrances. Verhandlungen der Internationalen Vereinigung für Theoretische und Angewandte Limnologie, 26, 1442-
1444.

Fassbender, H. W. (1973), Simulate P-Bestinmung in in N-Kjeldahl Ausfschlub von Bodenproben. Die Phosphörsäure, 30, 44-53.

FIDERJ (1977), Estudos para o planejamento municipal. Macaé, Rio de Janeiro.

Furtado, A. L. S. and Esteves, F. A. (1997), Biological nitrogen fixation in a brazilian coastal lagoon Arquivos de Biologia e Tecnologia, 40, 143-151.

Golterman, H. L.; Clymi, R. S. and Ohmstad, A. M. (1978), Methods for Physical and Chemical Analysis of Fresh Water. Blackwell Scientific Publishers, Oxford.

Gonçalves Jr., J. F.; Callisto, M. and Leal, J. J. F. (1998), Relação entre a composição granulométrica do sedimento e as comunidades de macroinvertebrados bentônicos nas lagoas Imboacica, Cabiúnas e Comprida.. In-Ecologia das lagoas costeiras do Parque Nacional da Restinga de Jurubatiba e do Município de Macaé (RJ), ed. F. A. Esteves. UFRJ/NUPEM, Rio de Janeiro, pp. 299-310.

Harada, H.; Uemura, S. and Momonoi, K. (1994), Interaction between sulfate-reducing bacteria and methane-producing bacteria in USAB reactors fed with low strength wastes containing different levels of sulfate. Water Research, 28, 355-367.

Hungria, M. and Araújo, R. S. (editores) (1994), Manual de métodos empregados em estudos de microbiologia agrícola. EMBRAPA, Brasília.

Koroleff, F. (1983), Determination of ammonia. InMethods of Seawater Analysis, ed. K. Grasshoff; M. Ehrhardt and K. Kremling. Verlag Chemie, Weinheim, $2^{\mathrm{a}}$ edition, pp. 150-157.

Lopes-Ferreira, C. (1998), Redução das concentrações de nitrogênio e fósforo dos efluentes domésticos lançados na lagoa Imboacica, através de uma região colonizada por macrófitas aquáticas. In-Ecologia das lagoas costeiras do Parque Nacional da Restinga de Jurubatiba e do Município de Macaé (RJ), ed. F. A. Esteves. UFRJ/NUPEM, Rio de Janeiro, pp. 375-389.

Luther, G. W. III; Brendel, P. J.; Lewis, B. L.; Sundby, B.; Lefrancois, L.; Silverberg, N. and Nuzzio, D. B. (1998), Simultaneous measurements of $\mathrm{O}_{2}, \mathrm{Mn}, \mathrm{Fe}, \mathrm{I}-$, and $\mathrm{S}$ (II) in marine pore waters with a solid-state voltametric microeletrode. Limnology and Oceanography, 43, 325-333.

Mackereth, F. J. H.; Heron, J. and Talling, J. F. (1978), Forms of Nitrogen. In: Water Analysis: Some Revised Methods for Limnologists. Scientific Publication $\mathrm{n}^{\circ}$. 36, Freshwater Biological Association, Cumbria and Dorset, England. pp. 69-77.

Panosso, R. F.; Attayde, J. L. and Muehe, D. (1998), Morfometria das lagoas Imboacica, Cabiúnas, Comprida e Carapebus: implicações para seu funcionamento e manejo. In-Ecologia das lagoas 
costeiras do Parque Nacional da Restinga de Jurubatiba e do Município de Macaé (RJ), ed. F. A. Esteves. UFRJ/NUPEM, Rio de Janeiro, pp. 91-108.

Petrucio, M. M. (1998), Caracterização das lagoas Imboacica, Cabiúnas e Comprida e Carapebus a partir da temperatura, salinidade, condutividade, alcalinidade, $\mathrm{O}_{2}$ dissolvido, $\mathrm{pH}$, transparência e material em suspensão. In-Ecologia das lagoas costeiras do Parque Nacional da Restinga de Jurubatiba e do Município de Macaé (RJ), ed. F. A. Esteves. UFRJ/NUPEM, Rio de Janeiro, pp. 109-122.

Ratering, S. and Conrad, R. (1998), Effects of short-term drainage and aeration on the production of methane in submerged rice soil. Global Change Biology, 4, 397-407.

Sass, H.; Cypionka, H. and Babenzien, H.-D. (1997), Vertical distribution of sulfate-reducing bacteria at the oxic-anoxic interface in sediments of the oligotrophic Lake Stechlin. FEMS Microbiology Ecology, 22, 245-255.

Segers, R. (1998), Methane production and methane consumption: a review of processes underlying wetland methane fluxes. Biogeochemistry, 41, 23-51.

Takai, K. and Sako, Y. (1999), A molecular view of archaeal diversity in marine and terrestrial hot water environments. FEMS Microbiology Ecology, 28, 177188.

Zaiss, U. (1996), A comparison of hydrogen sulphide, hydrogen and methane production and consumption in different aquatic ecosystems. Mitteilungen der Internationalen Vereinigung für Limnologie, 25, 63-71.

Zink, K. G.; Furtado, A. L. S., Casper, P. and Schwark, L. (submitted), Organic matter composition in the sediment of three Brazilian coastal lagoons - District of Macaé, Rio de Janeiro (Brazil). Environmental Geology.
Whiticar, M. J. (1996), Isotope tracking of microbial methane formation and oxidation. Mitteilungen der Internationalen Vereinigung für Limnologie, 25, 39-54. 